\title{
Field evaluation of fungicides for control of blast of rice (Pyricularia grisea Sacc.)
}

\author{
Boyapati Ravi Teja Naidu` and Manoj Kumar Barnwal \\ Department of Plant Pathology, Birsa Agricultural University, Ranchi-834006, Jharkhand, India
}

\section{Article Info}

Article history

Received 1 May 2021

Revised 17 June 2021

Accepted 18 June 2021

Published online 30 June 2021

\section{Keywords}

Efficacy trial

Fungicides

Grain yield

Oryza sativa $\mathrm{L}$

Pyricularia grisea Sacc.

\begin{abstract}
Blast of rice disease caused by the ascomycete fungus, Magnaporthe oryzae (Hebert) Barr. (Anamorph: Pyricularia grisea Sacc.). It is one of the most devastating diseases of rice. Considering the economic importance of the disease, $P$. grisea can be most notorious and model species of rice diseases, causing significant reduction in yield. In vivo evaluation of fungicides against blast of rice, two sprays of Prochloraz@ $2 \mathrm{ml} / \mathrm{lit}$ was recorded to be the most efficacious fungicide in reducing lowest leaf blast disease severity of $9.1 \%$ and neck blast incidence of $5.7 \%$ and highest grain yield of $42.00 \mathrm{q} / \mathrm{ha}$, highest benefit-cost ratio of 1:3.90 and net return of Rs. 14290.35 per ha. Spore appressorium and germ tube induction and cells are alive in water spray for infection and spore appressorium and germ tube death was observed in Prochloraz 45\% EC two sprays.
\end{abstract}

\section{Introduction}

Rice (Oryza sativa L.) is one of the most important cereal crops of the world and a major staple food for half of the world's human population (Singh and Singh, 2019). More than $90 \%$ of the world's rice is grown and consumed in Asia, where $60 \%$ of the global population lives, so Asia is the key for global food security (Bandamula 2018). India has major share $(28 \%)$ of world's rice producing area. In world, the cropped area of rice is $159.80 \mathrm{~m}$. ha, production is $740.96 \mathrm{~m}$. tons and productivity is $4630 \mathrm{~kg} / \mathrm{ha}$ whereas, in India, rice is grown in $43.8 \mathrm{~m}$. ha, the production of $168.5 \mathrm{~m}$. tons and the productivity of about $3848 \mathrm{~kg} / \mathrm{ha}$. In Jharkhand, rice is grown in an area of 18.0 lakh ha, the production and productivity of 3.27 lakh tons and $1814 \mathrm{~kg} / \mathrm{ha}$, respectively during 2016-17 (Jena, Somu 2015). At present, the productivity of rice in Jharkhand is very low in comparison to other states of India. It may be due to lack of knowledge, unavailability of high yielding varieties of rice, yield loss due to biotic and abiotic factors, etc.

Among biotic factors, diseases are of prime importance. The major diseases like a blast, brown spot, false smut, sheath blight, bacterial blight, and sheath rot, etc., causing damage to the rice crop across the world. The Commonwealth Mycological Institute, London has recorded its presence from 85 countries throughout the world. Among diseases, rice blast, caused by $P$. grisea (Perfect stage - M. oryzae) is one of the most important fungal disease causing heavy loss of rice yield.

Many of the control practices are useful in reducing plant diseases are of limited use against rice blast as this pathogen is highly variable

Corresponding author: Mr. Boyapati Ravi Teja Naidu Department of Plant Pathology, Birsa Agricultural University, Ranchi834006, Jharkhand, India

E-mail: ravitejanaiduboyapati@gmail.com

Tel.: +91-9182982439

Copyright (C) 2021 Ukaaz Publications. All rights reserved.

Email: ukaaz@yahoo.com; Website: www.ukaazpublications.com and the virulence factors present in one population might be absent in another geographically isolated population (Pooja and Katoch 2014). Because of high variability in blast pathogen, varieties frequently succumb to this disease. Use of fungicide is still the most feasible method for managing this disease. From time-to-time various chemicals are tested for the management of rice blast disease (Raj and Pannu, 2017; Singh et al., 2019). Uses of fungicides can effectively increasing the yield of farmers in rainfed areas against blast (Barnwal, 2014).

\section{Materials and Methods}

To determine the efficacy of new seven fungicides (five systemic and two combination products) formulations for management of blast of rice, a field trial was conducted during Kharif, 2019-20 crop season at Rice Research Farm, Birsa Agricultural University, Ranchi. Rice seeds (Variety Pusa Sugandha-3) were sown in $5.4 \mathrm{~m} \times 3.3 \mathrm{~m}$ plots with a spacing of $20 \mathrm{~cm}$ (row-to-row) and $15 \mathrm{~cm}$ (plant-toplant). The trial was laid out in RBD with three replications. The nursery sowing was done in $19^{\text {th }}$ July, 2019 and transplanting was done in $16^{\text {th }}$ August, 2019 with seed rate of $40 \mathrm{~kg} \mathrm{ha}^{-1}$. The plots were fertilized with NPK @ 80:40:30 kg ha-1, respectively. Nitrogen was applied in three split doses (i.e., 30,25 and $25 \mathrm{~kg} \mathrm{ha}^{-1}$ ) at transplanting, tillering and panicle initiation stages of crop growth. Phosphorus and potassic fertilizers were applied @ 40:30 kg ha-1 as basal. Ecology- rainfed low land (Don I). There were eight treatments including control. The necessary agronomic inputs were provided during crop season 28 days after transplanting (DAT) of rice were sprayed with the spore suspension of $P$. grisea having spore load of $1 \times 10^{6}$ spores $/ \mathrm{ml}$ of sterilized distilled water. The spore suspension was sprayed in the evening to provide 12 hours of humid environment for easy establishment of the pathogen. Two consecutive sprays of fungicides were given as per the treatments (i.e., 30 and 40 DAT). Untreated plot was served as control. Observation on per cent disease index (PDI) or disease severity of leaf blast was recorded after ten 
days of last spray by observing fifty leaves per plot randomly. PDI can be calculated by following formula:

$$
\text { PDI }=\frac{\text { Total sum of numerical rating }}{\text { Total number of samples taken } X \text { Maximum grade }} \times 100
$$

Neck blast incidence was recorded seven days before harvest by observing one hundred panicles per plot randomly. Grain yields were recorded for each plot after threshing and sun drying for seven days. The per cent disease control (PDC) over control was calculated as:

PDC over control,

$$
=\frac{\text { PDI in control }\left(\mathrm{T}_{\mathrm{C}}\right)-\text { PDI intreatment }(\mathrm{T})}{\text { PDI in control }\left(\mathrm{T}_{\mathrm{C}}\right)} \times 100
$$

The grain yield and straw yield in each plot was recorded separately. Increase in grain yield over control was also calculated and $\mathrm{B}: \mathrm{C}$ ratio of each treatment was also worked out. Cost- benefit ratio for various treatments was worked out as follows:

$$
\text { Cost-benefit ratio }=\frac{\text { Net return (Rs ha- } 1)}{\text { Cost of input (Rs ha-1) }}
$$

Fungicidal action of each treatment was observed five days after spraying, the leaf blast samples of each treatment were brought into the laboratory and thoroughly washed with sterilized water to remove dust or soil particles. These samples were then placed on a sterilized filter paper to remove excess moisture. The leaf samples were incubated under humid chamber at $95 \%$ relative humidity and $28^{\circ} \mathrm{C}$ for 8-12 hrs. Spore germination of $P$. grisea was observed on

\begin{tabular}{|c|c|c|c|c|}
\hline S.No. & Chemical name & Trade name & Dose (g or $\mathrm{ml} / \mathrm{l}$ of water) & Reference \\
\hline \multicolumn{5}{|c|}{ Systemic fungicides } \\
\hline $\mathrm{T}_{1}$ & Prochloraz $45 \%$ EC & Sportak & $2.0 \mathrm{ml}$ & Magar et al, 2015 \\
\hline $\mathrm{T}_{2}$ & Hexaconazole 5\% EC & Contaf & $2.0 \mathrm{ml}$ & Prasanna Kumar et al, 2011 \\
\hline $\mathrm{T}_{3}$ & Tricyclazole $75 \%$ WP & Gain & $0.6 \mathrm{~g}$ & Anwar and Bhat, 2005 \\
\hline $\mathrm{T}_{4}$ & Propiconazole $25 \%$ EC & Tilt & $1.0 \mathrm{ml}$ & $\begin{array}{l}\text { Prasanna Kumar and } \\
\text { Veerabhadraswamy, } 2014\end{array}$ \\
\hline $\mathrm{T}_{5}$ & Difenoconazole $25 \%$ EC & Score & $1.0 \mathrm{ml}$ & Singh et al, 2019 \\
\hline \multicolumn{5}{|c|}{ Combination products } \\
\hline $\mathrm{T}_{6}$ & $\begin{array}{l}\text { Prochloraz } 23.5 \% \mathrm{~W} / \mathrm{W}+ \\
\text { Tricyclazole } 20.0 \% \mathrm{~W} / \mathrm{W} \mathrm{SC}\end{array}$ & - & $2.0 \mathrm{ml}$ & Pramesh et al, 2020 \\
\hline $\mathrm{T}_{7}$ & $\begin{array}{l}\text { Azoxystrobin } 18.2 \% \mathrm{~W} / \mathrm{W}+ \\
\text { Difenoconazole } 11.4 \% \mathrm{~W} / \mathrm{W} \text { SC }\end{array}$ & Amistar top & $1.0 \mathrm{ml}$ & Singh et al, 2019 \\
\hline $\mathrm{T}_{8}$ & Control & - & - & - \\
\hline
\end{tabular}
leaves of each treatment under compound microscope.

Table 1: List of fungicides used in the experiment

\section{Results}

To evaluate the efficacy of seven fungicides, viz., prochloraz $23.5 \%$ $\mathrm{W} / \mathrm{W}+$ tricyclazole $20.0 \% \mathrm{~W} / \mathrm{W} \mathrm{SC}$, prochloraz $45 \% \mathrm{EC}$, tricyclazole $75 \% \mathrm{WP}$, azoxystrobin $18.2 \% \mathrm{~W} / \mathrm{W}+$ difenoconazole $11.4 \% \mathrm{~W} / \mathrm{W}$ SC, difenoconazole $25 \%$ EC, hexaconazole $5 \%$ EC, propiconazole $25 \%$ EC against blast of rice; a field trial was conducted during kharif, 2019-20 crop season. The experimental details have been given in materials and methods (Table 1).

All of the fungicides significantly reduce the leaf blast disease severity in comparison to control. Lowest leaf blast disease severity of $9.1 \%$ and neck blast incidence of $5.7 \%$ were recorded when two sprays of prochloraz@ $2 \mathrm{ml} /$ lit were given. This treatment also recorded decrease in leaf blast over control (DLBOC) of 74.7\%, decrease in neck blast over control (DNBOC) of $70.0 \%$, highest grain yield of $42.00 \mathrm{q} / \mathrm{ha}$ and increase in grain yield over control (IYOC) of $30.8 \%$. This treatment was followed by two sprays of prochloraz + tricyclazole @ $2 \mathrm{ml} /$ lit, which recorded leaf blast disease severity of $11.5 \%$ and neck blast incidence of $7.0 \%$, DLBOC (68.0\%), DNBOC
(63.2\%), grain yield of $40.11 \mathrm{q} / \mathrm{ha}$ and IYOC of $24.9 \%$. The next best treatment in order of superiority was two sprays of tricyclazole @ $0.6 \mathrm{~g} / \mathrm{lit}$, which recorded leaf blast disease severity of $13.8 \%$ and neck blast incidence of $8.0 \%$, grain yield of $39.33 \mathrm{q} / \mathrm{ha}$, DLBOC of $61.6 \%$, DNBOC of $57.9 \%$ and IYOC of $22.5 \%$. The next best treatment was two sprays of azoxystrobin + difenoconazole @ 1 $\mathrm{ml} /$ lit, which recorded leaf blast disease severity of $15.3 \%$ and neck blast incidence of $8.3 \%$, grain yield of $37.33 \mathrm{q} / \mathrm{ha}$, DLBOC of $57.4 \%$, DNBOC of $56.3 \%$ and IYOC of $16.3 \%$. Whereas, the control plots recorded disease severity leaf blast and neck blast incidence of $35.9 \%$ and $19.0 \%$, respectively and rice grain yield of $32.11 \mathrm{q} / \mathrm{ha}$ (Table 2 ).

Yield attributing characters were also recorded which were depicted in Table 3. All the yield attributing traits were superior in plots having two sprays of prochloraz @ $2 \mathrm{ml} / \mathrm{lit}$ in comparison to other treatments. This treatment also recorded highest number of grains/ panicle (159) and highest number of tillers $/ \mathrm{m}^{2}$ (232.3) which were significantly superior over control whereas, other yield attributing characters like plant height $(136.2 \mathrm{~cm})$, panicle length $(24.9 \mathrm{~cm})$ and 
1000 grain weight ( $27.44 \mathrm{~g}$ ) were higher in comparison to control but they were non-significant in comparison to control. This treatment was followed by two sprays of prochloroz + tricyclazole @ $2 \mathrm{ml} / \mathrm{lit}$, which recorded number of grains/panicle (156) and number of tillers per $\mathrm{m}^{2}$ (224.0) which were significantly superior over control whereas, other characters like plant height $(133.3 \mathrm{~cm})$, panicle length $(23.3 \mathrm{~cm})$ and 1000 grain weight $(27.31 \mathrm{~g})$ was higher in comparison to control, but they were non-significant in comparison to control. Whereas, the control plot recorded number of grains/panicle (124) and number of tillers per $\mathrm{m}^{2}(179.3)$, plant height $(128.4 \mathrm{~cm})$, panicle length $(21.8 \mathrm{~cm})$ and 1000 grain weight $(26.58 \mathrm{~g})$

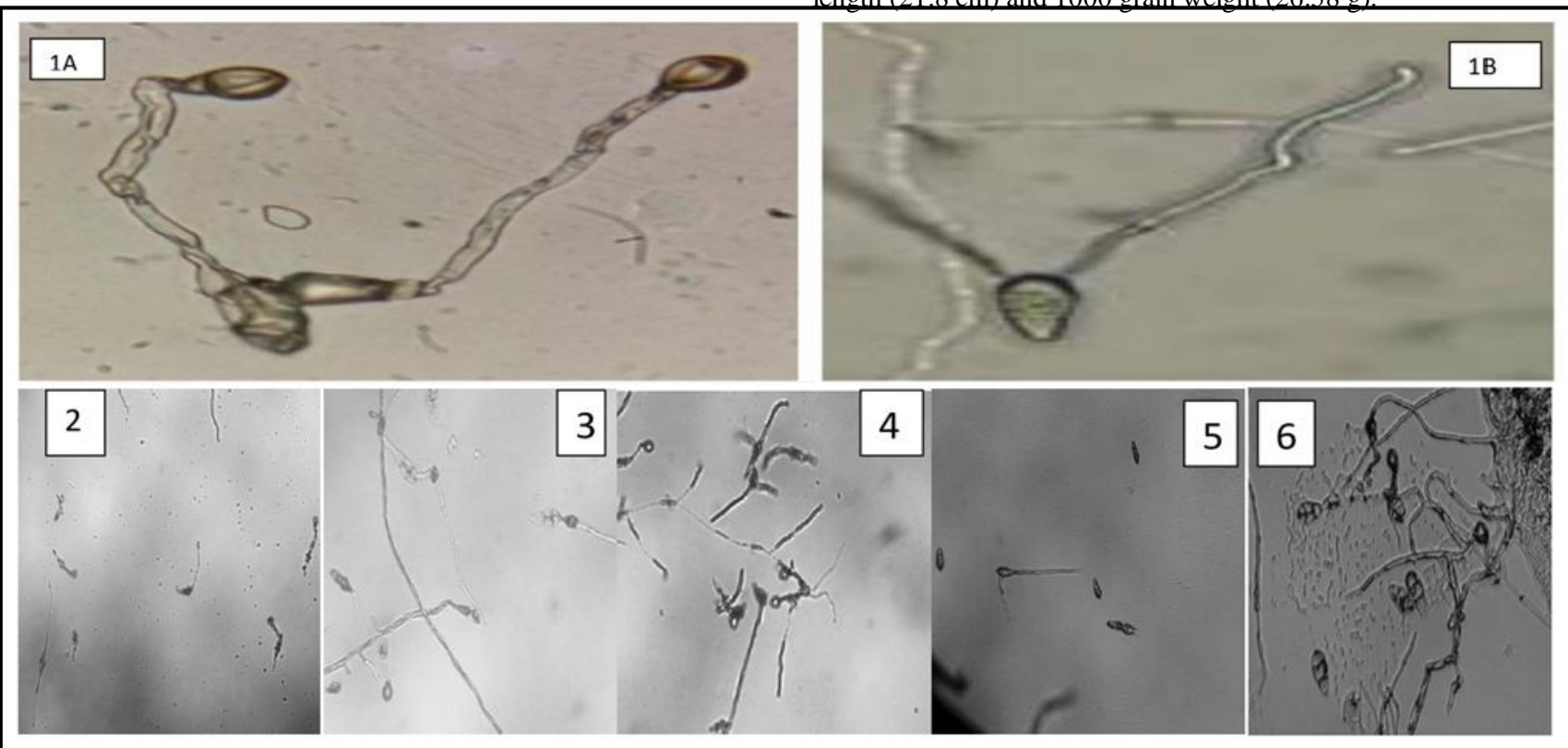

Figures 1-6: Spore appressorium and germ tube induction.

1. (A) Spore produce appressorium with germ tube (Control plot).

1. (B) Spore germination with germ tube (Control plot).

2. Prochloraz $45 \%$ EC plot no appressorium induction and fungicidal action was noted.

3. Prochloraz $23.5 \% \mathrm{~W} / \mathrm{W}+$ tricyclazole $20 \% \mathrm{~W} / \mathrm{W}$ SE appressorium induced but death appressorium was seen after two sprays.

4. Tricyclazole $75 \% \mathrm{WP}$ germ tube and appressorium induction but $30 \%$ alive and remaining dead.

5. Azoxytrobin $18.2 \%$ + difenoconazole $11.4 \% \mathrm{~W} / \mathrm{W}$ SC No germ tube produced but all spores are alive.

6. Hexaconazole $5 \% \mathrm{EC}$ germ tube and appressorium are formed mostly $60 \%$ appressorium are not undergo autophagy.

Table 2: In vivo evaluation of newer fungicides for management of blast and yield of rice (Kharif, 2019)

\begin{tabular}{|c|c|c|c|c|c|c|}
\hline Treatments & $\begin{array}{l}\text { *Leaf blast } \\
\text { (PDI-\%) }\end{array}$ & $\begin{array}{l}\text { DLB OC } \\
(\%)\end{array}$ & $\begin{array}{l}\text { *Neck } \\
\text { blast }(\%)\end{array}$ & $\begin{array}{l}\text { DNBOC } \\
(\%)\end{array}$ & $\begin{array}{l}* \text { Grain } \\
\text { yield } \\
(\text { q/ha })\end{array}$ & $\begin{array}{l}\text { IY OC } \\
(\%)\end{array}$ \\
\hline $\begin{array}{l}\mathrm{T}_{1} \text {. two spray of prochloraz } 23.5 \% \mathrm{~W} / \mathrm{W}+ \\
\text { tricyclazole 20\% W/W SE @ } 2.0 \mathrm{ml} / \mathrm{l} .\end{array}$ & $11.5(19.7)$ & 68.0 & $7.0(15.0)$ & 63.2 & 40.11 & 24.9 \\
\hline $\mathrm{T}_{2}$. two spray of prochloraz 45\% EC @ $2.0 \mathrm{ml} / 1$. & $9.1(17.4)$ & 74.7 & $5.7(13.5)$ & 70.0 & 42.00 & 30.8 \\
\hline $\mathrm{T}_{3}$. two spray of tricyclazole 75\% WP @ $0.6 \mathrm{~g} / 1$. & $13.8(21.6)$ & 61.6 & $8.0(16.3)$ & 57.9 & 39.33 & 22.5 \\
\hline $\begin{array}{l}\mathrm{T}_{4} \cdot \text { two spray of azoxytrobin } 18.2 \%+ \\
\text { difenoconazole } 11.4 \% \text { W/W SC @ } 1.0 \mathrm{ml} / \mathrm{l} \text {. }\end{array}$ & $15.3(22.9)$ & 57.4 & $8.3(16.6)$ & 56.3 & 37.33 & 16.3 \\
\hline $\mathrm{T}_{5}$. two spray of difenoconazole 25\% EC @ $1.0 \mathrm{ml} / \mathrm{l}$. & $17.9(24.7)$ & 50.1 & $11.3(19.6)$ & 40.5 & 36.78 & 14.5 \\
\hline $\mathrm{T}_{6}$. two spray of hexaconazole 5\% EC @ $2.0 \mathrm{ml} / 1$. & $23.0(28.7)$ & 35.9 & $11.0(19.2)$ & 42.1 & 34.11 & 6.2 \\
\hline $\mathrm{T}_{7}$. two spray of propiconazole 25\% EC @ $1.0 \mathrm{ml} / 1$. & $26.1(29.5)$ & 27.3 & $14.7(22.4)$ & 22.6 & 35.00 & 9.0 \\
\hline $\mathrm{T}_{8}$ control (water spray) & $35.9(36.8)$ & - & $19.0(25.7)$ & - & 32.11 & - \\
\hline $\operatorname{S~Em~}( \pm)$ & 2.3 & & 2.0 & & 1.6 & \\
\hline $\mathrm{CD}$ at $5 \%$ & 7.0 & & 6.0 & & 4.8 & \\
\hline $\mathrm{CV}(\%)$ & 12.9 & & 18.6 & & 17.4 & \\
\hline
\end{tabular}

DLBOC-Decrease in leaf blast over control DNBOC-Decrease in neck blast over control IYOC-Increase in yield over control. Figures in parentheses are transformed arc sine values * Mean of three replications 
Table 3: In vivo evaluation fungicides on yield attributing characters of rice (Kharif, 2019)

\begin{tabular}{|c|c|c|c|c|c|c|}
\hline \multirow[b]{2}{*}{ Treatments } & \multicolumn{5}{|c|}{ Yield attributing characters } & \multirow[b]{2}{*}{$\begin{array}{c}* 1000 \\
\text { grain } \\
\text { weight }(\mathrm{g})\end{array}$} \\
\hline & $\begin{array}{l}* \text { Yield } \\
(\mathbf{q} / \mathbf{h a})\end{array}$ & $\begin{array}{c}\text { *Plant } \\
\text { height } \\
(\mathbf{c m})\end{array}$ & $\begin{array}{l}\text { *Panicle } \\
\text { length } \\
\quad(\mathbf{c m})\end{array}$ & $\begin{array}{l}\text { *Number } \\
\text { of grains } \\
\text { /panicle }\end{array}$ & $\begin{array}{l}* \text { No. of } \\
\text { tillers } / \mathbf{m}^{2}\end{array}$ & \\
\hline $\begin{array}{l}\mathrm{T}_{1} \text {. two spray of prochloraz } 23.5 \% \mathrm{~W} / \mathrm{W}+ \\
\text { tricyclazole } 20 \% \text { W/W SE @ } 2.0 \mathrm{ml} / 1\end{array}$ & 40.11 & 133.3 & 23.3 & 156 & 224.0 & 27.31 \\
\hline $\mathrm{T}_{2}$. two spray of prochloraz $45 \%$ EC @ $2.0 \mathrm{ml} / \mathrm{l}$ & 42.00 & 136.2 & 24.9 & 159 & 232.3 & 27.44 \\
\hline $\mathrm{T}_{3}$. two spray of tricyclazole $75 \%$ WP @ $0.6 \mathrm{~g} / 1$ & 39.33 & 132.9 & 24.8 & 146 & 218.7 & 27.33 \\
\hline $\begin{array}{l}\mathrm{T}_{4} \cdot \text { two spray of azoxytrobin } 18.2 \% \\
+ \text { difenoconazole } 11.4 \% \text { W/W SC @ } 1.0 \mathrm{ml} / \mathrm{l}\end{array}$ & 37.33 & 131.8 & 22.2 & 140 & 210.0 & 26.97 \\
\hline $\mathrm{T}_{5}$. two spray of difenoconazole 25\% EC @ $1.0 \mathrm{ml} / 1$ & 36.78 & 131.2 & 23.9 & 137 & 210.6 & 27.10 \\
\hline $\mathrm{T}_{6}$. two spray of hexaconazole $5 \% \mathrm{EC} @ 2.0 \mathrm{ml} / 1$ & 34.11 & 130.1 & 21.2 & 130 & 185.3 & 26.93 \\
\hline $\mathrm{T}_{7}$. two spray of propiconazole 25\% EC @ $1.0 \mathrm{ml} / 1$ & 35.00 & 130.6 & 23.5 & 134 & 191.3 & 26.84 \\
\hline $\mathrm{T}_{8}$ control (water spray) & 32.11 & 128.4 & 21.8 & 124 & 179.3 & 26.58 \\
\hline $\mathrm{S} \operatorname{Em}( \pm)$ & 1.6 & & & 7.3 & 11.5 & \\
\hline $\mathrm{CD}$ at $5 \%$ & 4.8 & NS & NS & 22.3 & 34.8 & NS \\
\hline $\mathrm{CV}(\%)$ & 17.4 & & & 9.1 & 9.6 & \\
\hline
\end{tabular}

Table 4: Benefit-cost ratio of effect of fungicides for management of blast and yield of rice (Kharif, 2019)

\begin{tabular}{|c|c|c|c|c|c|c|}
\hline Treatments & $\begin{array}{c}* \text { Yield } \\
(\mathbf{q} / \mathbf{h a})\end{array}$ & $\begin{array}{l}\text { Additional } \\
\text { yield over } \\
\text { control } \\
(q / h a)\end{array}$ & $\begin{array}{c}\text { Value of } \\
\text { additional } \\
\text { yield } \\
\text { ha(Rs) }\end{array}$ & $\begin{array}{l}\text { Cost of } \\
\text { input/ha } \\
\text { (Rs.) }\end{array}$ & $\begin{array}{c}\text { Net } \\
\text { return/ha } \\
\text { (Rs.) }\end{array}$ & $\begin{array}{l}\text { B: C } \\
\text { ratio }\end{array}$ \\
\hline $\begin{array}{l}\mathrm{T}_{1} . \text { two spray of prochloraz } 23.5 \% \mathrm{~W} / \mathrm{W} \\
+ \text { tricyclazole } 20 \% \text { W/W SE @ } 2.0 \mathrm{ml} / \mathrm{l}\end{array}$ & 40.11 & 8.00 & 14520.00 & 5340 & 9180.00 & 1: 1.72 \\
\hline $\mathrm{T}_{2}$. two spray of prochloraz 45\% EC @ 2.0 ml/l. & 42.00 & 9.89 & 17950.35 & 3660 & 14290.35 & $1: 3.90$ \\
\hline $\begin{array}{l}\mathrm{T}_{3} \text {. two spray of tricyclazole } 75 \% \text { WP @ } 0.6 \mathrm{~g} / 1 \text {. } \\
\mathrm{T}_{4} \text {. two spray of azoxytrobin } 18.2 \%+\end{array}$ & 39.33 & 7.22 & 13104.30 & 2808 & 10296.30 & 1: 3.67 \\
\hline difenoconazole $11.4 \%$ W/W SC @ 1.0 ml/l. & 37.33 & 5.22 & 9474.30 & 4152 & 5322.30 & 1: 1.28 \\
\hline $\mathrm{T}_{5}$. two spray of difenoconazole 25\% EC @ $1.0 \mathrm{ml} / 1$. & 36.78 & 4.67 & 8476.05 & 6996 & 1480.05 & 1: 0.21 \\
\hline $\mathrm{T}_{6}$. two spray of hexaconazole 5\% EC @ $2.0 \mathrm{ml} / 1$. & 34.11 & 2.00 & 3630.00 & 2820 & 810.00 & 1: 0.29 \\
\hline $\mathrm{T}_{7}$. two spray of propiconazole 25\% EC @ $1.0 \mathrm{ml} / 1$. & 35.00 & 2.89 & 5245.35 & 3420 & 1825.35 & 1: 0.53 \\
\hline $\mathrm{T}_{8 .}$ control (water spray) & 32.11 & - & - & - & - & - \\
\hline \multicolumn{3}{|c|}{ 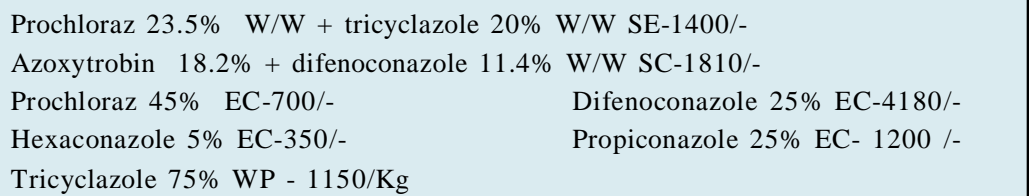 } & \multicolumn{4}{|c|}{$\begin{array}{l}\text { Labour required/ spray - } 3 \text { man days/ha } \\
\text { Labour charge - Rs } 280 / \text { day } \\
\text { Hiring charge of sprayer - Rs } 50 / \text { day } \\
\text { Miscellaneous - Rs } 100 / \text { ha } \\
\text { Cost of rice (Rs/q) - } 1815 /-\end{array}$} \\
\hline
\end{tabular}

Highest benefit-cost ratio of 1:3.90 was found in the treatment, i.e., two sprays of prochloraz @ $2 \mathrm{ml} /$ lit. This treatment also recorded an additional grain yield over control of $9.89 \mathrm{q} / \mathrm{ha}$ and net return of Rs. 14290.35 per ha. This treatment was followed by treatment having two sprays of tricyclazole @ $0.6 \mathrm{~g} / \mathrm{lit}$, which recorded a benefit-cost ratio of 1:3.67, an additional yield over control of 7.22 q/ha and a net return of Rs. 10296.30 per ha. The next best treatment in order of superiority was two sprays of prochloroz + tricyclazole @ $2 \mathrm{ml} /$ lit, which recorded a benefit-cost ratio of 1:1.72, an additional grain yield over control of $8.0 \mathrm{q} / \mathrm{ha}$ and a net return of Rs.9180.0 per ha. This next best treatment was two sprays of azoxystrobin + difenoconazole SC @ 1 ml/lit, which recorded a benefit-cost ratio of $1: 1.28$, an additional grain yield over control of $5.22 \mathrm{q} / \mathrm{ha}$ and a net return of Rs. 5322.30 per ha (Table 4). 
Fungicidal action was observed in spore (P. grisea) germination after spraying of treatments and checks in plots; the details of the experiment as given in material and methods (Table 1). In control plot, the spore was germinated and appressorium were formed, but in plots having prochloraz $45 \%$ EC were applied recorded most of the spores are not germinated. The germinated spores with appressorium are dead and were seen under compound microscope whereas, the plots which are sprayed with prochloraz $23.5 \% \mathrm{~W} / \mathrm{W}$ + tricyclazole $20 \% \mathrm{~W} / \mathrm{W}$ SE recorded no spore germination were observed but death of spores were not observed in both tricyclazole 75\% WP germ tube and appressorium induction but $30 \%$ alive and remaining dead; azoxytrobin $18.2 \%$ + difenoconazole $11.4 \% \mathrm{~W} / \mathrm{W}$ SC No germ tube produced but all spores are alive under compound microscope. In other treatments, no fungicidal actions were observed as like in treatment of prochloraz (Figure 1).

\section{Discussion}

Efficacy of seven fungicides viz., prochloraz $23.5 \% \mathrm{~W} / \mathrm{W}+$ tricyclazole $20.0 \% \mathrm{~W} / \mathrm{W}$ SC, prochloraz $45 \% \mathrm{EC}$, tricyclazole $75 \%$ $\mathrm{WP}$, azoxystrobin $18.2 \% \mathrm{~W} / \mathrm{W}+$ difenoconazole $11.4 \% \mathrm{~W} / \mathrm{W} \mathrm{SC}$, difenoconazole $25 \%$ EC, hexaconazole $5 \%$ EC, propiconazole $25 \%$ EC were evaluated against blast of rice under field conditions. All of the fungicides reduce the leaf blast disease severity in comparison to control. Lowest leaf blast disease severity of $9.1 \%$ and neck blast incidence of $5.7 \%$ were recorded when two sprays of prochloraz @ $2 \mathrm{ml} /$ lit were given. This treatment also recorded highest grain yield of $42.00 \mathrm{q} / \mathrm{ha}$, increase in grain yield over control (IYOC) of $30.8 \%$, benefit-cost ratio of 1:3.90 and net return of Rs 14290.35 per ha. The mode of action of prochloraz fungicide inhibits the demethylation during ergosterol formation, thus damaging the cell membrane integrity of the rice blast fungi. It indicates that prochloraz has significant impact on rice blast spore death and germination. This treatment was followed by two sprays of prochloraz + tricyclazole @ $2 \mathrm{ml} / \mathrm{lit}$, which recorded leaf blast disease severity of $11.5 \%$, neck blast incidence of $7.0 \%$, DLBOC $(68.0 \%)$, DNBOC $(63.2 \%)$, grain yield of $40.11 \mathrm{q} / \mathrm{ha}$, IYOC of $24.9 \%$, benefit-cost ratio of $1: 1.72$ and a net return of Rs. 9180.0 per ha. Indeed with Muralidharan and Dinaker (2007) reported that highest reduction in neck blast incidence was observed when tricyclazole was given this treatment, increased grain yield by 41 and $87 \%$ in 2000 and 2001, respectively.

Barnwal et al. (2012) tested six new fungicide formulations for their efficacy to control rice blast, RIL 0.13 SDC (fenoxanil + isoprothiolane)@ $0.2 \%$ was most effective in controlling disease with leaf blast severity of $8.8 \%$ and neck blast incidence of $4.7 \%$ and gave highest yield of rice.

Magar et al. (2015) conducted field trials on management of blast of rice with many fungicides. Application of tricyclazole $22 \%+$ hexaconazole $3 \% \mathrm{SC}$ was found to be the most effective with least leaf blast severity $(6.23 \%)$, neck blast incidence $(8.97 \%)$, and highest percent disease control (87.1\% and 79.6\%) in leaf blast and neck blast, respectively, and grain yield ( $4.23 \mathrm{t} / \mathrm{ha}$ ) followed by prochloraz $25 \%$ EC $(0.3 \%)$ and hexaconazole $3 \%$ SC $(0.2 \%)$.

Ghimire (2017) reported that tricyclazole appeared better followed by hexaconazole determined in terms of disease incidence, disease index, test weight and total yield with $T$. viride appeared quite comparable to tricyclazole.
Singh et al. (2019) tested the efficiency of different fungicides against blast of rice. Minimum disease intensity and highest yield was recorded in tebuconazole $50 \%+$ trifloxystrobin $25 \%$, followed by azoxystrobin $18.2 \%$ + difenoconazole $11.4 \%$.

\section{Conclusion}

From the present studies, these attributes supports that efficacy of seven fungicides against blast of rice disease. All of the fungicides reduce the leaf blast disease severity in comparison to control. Prochloraz fungicide was the most effective fungicide in inhibition of spore germination along with lowest leaf blast severity, neck blast incidence and highest yield. Followed by two sprays of prochloraz + tricyclazole fungicide dead appresorium was observed, tricyclazole, azoxytrobin + difenoconazole, difenoconazole are effective in fungicidal action to control the rice blast disease. The results obtained may be helpful to the farmers to effectively control the rice blast disease and obtain high yield in rice crop.

\section{Acknowledments}

We would like to thank NAHEP, BAU Ranchi for funding and supporting this research.

\section{Conflict of interest}

The authors declare that there are no conflicts of interest relevant to this article.

\section{References}

Anwar, A. and Bhat, M.S. (2005). Efficacy of fungicides as seed treatment in the management of blast disease of rice in nursery bed. Agric. Sci. Digest, 25(4):293-295.

Bandumula, N. (2018). Rice production in Asia: Key to global food security. Proceedings of the National Academy of Sciences, India Section B: Biological Sciences, 88(4):1323-1328.

Barnwal, M.K. (2014). Management of location specific rice diseases under rainfed ecosystem through host resistance and biopesticides. Progressive Research, 9:22-24.

Barnwal, M.K.; Singh, V. K.; Sharma, R. B. and Singh, B. N. (2012). Field evaluation of rice genotypes for resistance and new fungicides for control of blast (Pyricularia oryzae). Indian Phytopathology, 65(1):56-59.

Ghimire, P. (2017). Evaluation of fungicides and bioagent against neck blast disease of rice. Journal of Plant Pathology and Microbiology, pp:8-12.

Jena, Somu. (2015). A prediction on rice production in India through multivariate regression analysis. Journal of Business and Management Sciences, 3(1):26-31.

Khush, G.S. and Jena, K.K. (2009). Current status and future prospects for research on blast resistance in rice (Oryza sativa L.). Advances in Genetics, Genomics and Control of Rice Blast Disease, pp:1-10.

Magar, P.B.; Acharya, B. and Pandey, B. (2015). Use of chemical fungicides for the management of rice blast (Pyricularia grisea) disease at Jyotinagar, Chitwan, Nepal. International Journal of Applied Sciences and Biotechnology, 3(3):474-478.

Muralidharan, K. and Dinaker, C. (2007). Quantitative assessment of spore production from leaf, node and neck blast lesions in rice. Journal of Mycology and Plant Pathology, 37(2):215-225.

Pooja, K. and Katoch, A. (2014). Past, present and future of rice blast management. Plant Science Today, 1:165-173. 
Prasanna Kumar, M.K.; Siddegowda, D.K.; Atheekur Rehaman, H.M..; Pandurange Gowda, K.T. and Sudarshan, G.K. (2011). New strobilurin group fungicide in rice disease management. Pestology, 35(9):34-39.

Pramesh, D.; Chittaragi, A.; Nagaraj, T.; Saddamhusen, A.; Chidanandappa, E. Sharanabasav, H. and Gowdar, S. B. (2020). Bioefficacy of combination fungicide Prochloraz 27\%+ tricyclazole 23\% SE for the management of blast disease of rice. Journal of Pharmacognosy and Phytochemistry, 9(4):3027-3032.

Prasanna Kumar, M.K. and Veerabhadraswamy, A.L. (2014). Appraise a combination of fungicides against blast and sheath blight diseases of paddy (Oryza sativa L.). J. Exp. Biol. Agric. Sci., 2(1):49-57.
Raj, R. and Pannu, P.P.S. (2017). Management of rice blast with different fungicides and potassium silicate under in vitro and in vivo conditions. Journal of Plant Pathology, 99(3):707-712.

Singh, H.S.; Kaushik, S.S.; Chauhan, M.S. and Negi, R.S. (2019). Efficacy of different fungicides against rice blast caused by Pyricularia oryzae (Cav.) under field condition in Satna District, Madhya Pradesh. International Journal of Current Microbiology and Applied Science, 8(6):63-69.

Singh, S.P. and Singh, Y.T. (2019). Rice of North East India harbor rich genetic diversity as measured by SSR markers and $\mathrm{Zn} / \mathrm{Fe}$ content. BMC Genetics, 20(1):79. 